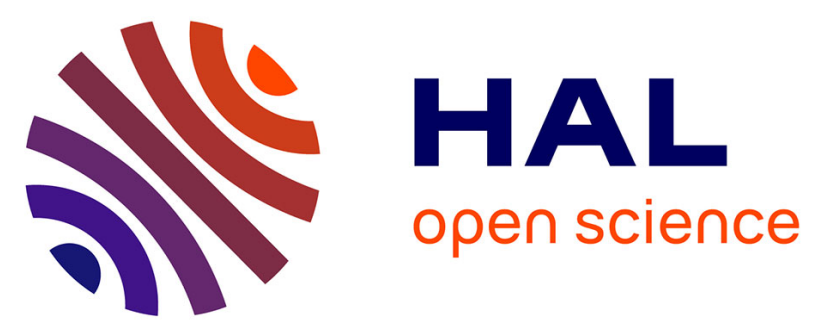

\title{
Pharmacokinetic and pharmacodynamic modelling of marbofloxacin administered alone and in combination with tolfenamic acid in calves
}

Pk Sidhu, Mf Landoni, Mhs Aliabadi, Pierre-Louis Toutain, Peter Lees

\section{- To cite this version:}

Pk Sidhu, Mf Landoni, Mhs Aliabadi, Pierre-Louis Toutain, Peter Lees. Pharmacokinetic and pharmacodynamic modelling of marbofloxacin administered alone and in combination with tolfenamic acid in calves. Journal of Veterinary Pharmacology and Therapeutics, 2011, 34 (4), pp.376-387. 10.1111/j.1365-2885.2010.01247.x . hal-01191156

\author{
HAL Id: hal-01191156 \\ https://hal.science/hal-01191156
}

Submitted on 1 Sep 2015

HAL is a multi-disciplinary open access archive for the deposit and dissemination of scientific research documents, whether they are published or not. The documents may come from teaching and research institutions in France or abroad, or from public or private research centers.
L'archive ouverte pluridisciplinaire HAL, est destinée au dépôt et à la diffusion de documents scientifiques de niveau recherche, publiés ou non, émanant des établissements d'enseignement et de recherche français ou étrangers, des laboratoires publics ou privés. 


\section{Pharmacokinetic and pharmacodynamic modelling of marbofloxacin administered alone and in combination with tolfenamic acid in calves}

\author{
P. K. SIDHU* \\ M. F. LANDONI ${ }^{\dagger}$ \\ M. H. S. ALIABADI \\ P. L. TOUTAIN ${ }^{\S} \&$ \\ P. LEES
}

*Department of Epidemiology and Preventive Veterinary Medicine, College of

Veterinary Science, Guru Angad Dev

Veterinary and Animal Science University,

Ludhiana, Punjab, India; ${ }^{\dagger}$ Catedra de

Farmacologia, Facultad de Ciencias

Veterinarias, Universidad Nacional de la

Plata, La Plata, Argentina; ${ }^{\star}$ Faroogh Life

Science Research Laboratory, Tohid Square,

Tehran, Iran; ${ }^{\S}$ Unité Associée INRA de

Physiopathologie et Toxicologie

Experimentales, Ecole Nationale Veterinaire

de Toulouse, Toulouse, France; ${ }^{\top}$ The Royal

Veterinary College, Hawkshead Campus,

Hatfield, Herts, UK

\begin{abstract}
Sidhu, P. K., Landoni, M. F., Aliabadi, M. H. S., Toutain, P. L., Lees, P. Pharmacokinetic and pharmacodynamic modelling of marbofloxacin administered alone and in combination with tolfenamic acid in calves. J. vet. Pharmacol. Therap. 34, 376-387.
\end{abstract}

In a four-period, cross-over study, the fluoroquinolone antibacterial drug marbofloxacin (MB) was administered to calves, alone and in combination with the nonsteroidal anti-inflammatory drug tolfenamic acid (TA). Both drugs were administered intramuscularly (IM) at doses of $2 \mathrm{mg} / \mathrm{kg}$. A tissue cage model of inflammation, based on the actions of the mild irritant carrageenan, was used to evaluate the pharmacokinetics (PK) of $\mathrm{MB}$ and $\mathrm{MB}$ in combination with TA. MB mean values of area under concentration-time curve (AUC) were $15.1 \mu \mathrm{g} \cdot \mathrm{h} / \mathrm{mL}$ for serum, $12.1 \mu \mathrm{g} \cdot \mathrm{h} / \mathrm{mL}$ for inflamed tissue cage fluid (exudate) and $9.6 \mu \mathrm{g} \cdot \mathrm{h} / \mathrm{mL}$ for noninflamed tissue cage fluid (transudate). Values of $C_{\max }$ were $1.84,0.35$ and $0.31 \mu \mathrm{g} / \mathrm{mL}$, respectively, for serum, exudate and transudate. Mean residence time (MRT) of $23.6 \mathrm{~h}$ (exudate) and $22.6 \mathrm{~h}$ (transudate) also differed significantly from serum MRT (8.6 h). Co-administration of TA did not affect the PK profile of MB. The pharmacodynamics of MB was investigated using a bovine strain of Mannheimia haemolytica. Time-kill curves were established ex vivo on serum, exudate and transudate samples. Modelling the ex vivo serum time-kill data to the sigmoid $\mathrm{E}_{\max }$ equation provided $\mathrm{AUC}_{24 \mathrm{~h}} / \mathrm{MIC}$ values required for bacteriostatic $(18.3 \mathrm{~h})$ and bactericidal actions $(92 \mathrm{~h})$ of $\mathrm{MB}$ and for virtual eradication of the organism was $139 \mathrm{~h}$. Corresponding values for MB + TA were 20.1, 69 and $106 \mathrm{~h}$. These data were used to predict once daily dosage schedules for a bactericidal action, assuming a $\mathrm{MIC}_{90}$ value of $0.24 \mu \mathrm{g} / \mathrm{mL}$, a dose of $2.6 \mathrm{mg} / \mathrm{kg}$ for $\mathrm{MB}$ and $2.19 \mathrm{mg} / \mathrm{kg}$ for $\mathrm{MB}+\mathrm{TA}$ were determined, which are similar to the currently recommended dose of $2.0 \mathrm{mg} / \mathrm{kg}$.

(Paper received 30 March 2010; accepted for publication 10 October 2010)

P. K. Sidhu, Department of Epidemiology and Preventive Veterinary Medicine, College of Veterinary Science, Guru Angad Dev Veterinary and Animal Science University, Ludhiana, Punjab, India 141004.E-mail: psidhu25@rediffmail.com

\section{INTRODUCTION}

Marbofloxacin (MB) is a fluoroquinolone developed for use in veterinary medicine. Its action is bactericidal and it possesses a wide spectrum of antimicrobial activity, which includes mycoplasmas, most gram-negative and some gram-positive bacteria (Spreng et al., 1995; Brown, 1996; Schneider et al., 1996; Thomas et al., 2003). Against most pathogens, its killing action is concentration dependent (Aliabadi \& Lees, 2002). Plasma protein binding is relatively low (Ismail \& El-Kattan, 2007). Clinical trials of $\mathrm{MB}$ for the treatment of bovine and porcine pneumonias have established its clinical efficacy under field conditions at a dose of $2 \mathrm{mg} / \mathrm{kg}$ once daily (Thomas et al., 1998a,b, 2001). In addition, it is also licensed to use for bovine respiratory disease $(\mathrm{BRD})$ at $8 \mathrm{mg} / \mathrm{kg}$ as a single dose.

Tolfenamic acid (TA) is a drug of the nonsteroidal antiinflammatory (NSAID) class. It is used in human and animals for its antihyperalgesic actions (Robertson \& Taylor, 2004). In addition, its anti-inflammatory, antipyretic and antihyperalgesic properties provide a pharmacological basis for its use in combination with antimicrobial drugs, in pneumonias of young calves and pigs. For example, TA has been used for BRD therapy in combination with oxytetracycline (Deleforge et al., 1994). Moreover, direct antimicrobial activity of TA has been reported in humans against Staphylococcus aureus, Escherichia coli and Pseudomonas aeruginosa (Kruszewska et al., 2002). Another drug 
of the NSAID class, diclofenac, has been shown, in a murine model of tuberculosis, to possess direct antimycobacterial activity, and it also interacts synergistically with streptomycin (Dutta et al., 2007).

As both MB and TA are licensed for the therapy of BRD and are marketed by the same manufacturer, it is probable that they are co-administered frequently in clinical use. Previous reports from our laboratory have described the effect of concurrent administration of MB on the PK of TA in calves (Sidhu et al., 2006a) and goats (Sidhu et al., 2006b). However, there are no published data on the influence of concurrent TA dosing on the PK of MB.

The aims of this investigation were to establish (i) the serum concentration-time profile and PK data; (ii) the rate and extent of penetration into and elimination from carrageenan-inflamed (exudate) and noninflamed (transudate) fluids in a tissue cage model; (iii) the ex vivo antibacterial activity in serum, exudate and transudate against a strain of $M$. haemolytica isolated from a clinical BRD case; and (iv) integration and modelling of PK and PD data as a basis for dosage determination of MB administered to calves both alone and in combination with TA.

\section{MATERIALS AND METHODS}

\section{Animals and surgical procedures}

The study was carried out in eight healthy male Holstein Friesian calves weighing 94-142 kg and aged 6-9 months. The animals had free access to hay and water and were given daily $1 \mathrm{~kg}$ of concentrate ration. Four cylindrical tissue cages prepared from silicone rubber tubing were inserted subcutaneously in each animal, two on each side of the flank as previously described (Sidhu et al., 2003). Animals were allowed to recover from surgery for 7 weeks to permit wound healing and the growth of granulation tissue into and around the cages.

\section{Experimental design and model of inflammation}

A four-period, four-sequence, four-treatment, cross-over design was used, such that each of eight calves received MB, TA, $\mathrm{MB}+\mathrm{TA}$ and placebo (PL) treatments in a randomized sequence, based on a Latin Square design. MB (Marbocyl 10\%; Vetoquinol Ltd., Lure Cedex, France) and TA (Tolfedine 4\%; Vetoquinol Ltd., UK) were supplied by the manufacturer. All injections were administered at zero time into the thigh muscles. Each drug was administered at the dose of $2 \mathrm{mg} / \mathrm{kg}$, with each calf receiving two injections in each period, into opposite thigh muscles. The PL injection was sterile normal saline. Intervals of 10 days were allowed between each period.

A volume of $0.5 \mathrm{~mL}$ of $1 \%$ sterile lambda carrageenan solution (Viscarin GP 109; Marine Colloids, Springfield, NJ, USA) was administered into one tissue cage at zero time during each treatment period (Sidhu et al., 2003). This cage was used to collect serial exudate samples $(1.5 \mathrm{~mL})$, and a noninjected tissue cage was used to collect serially samples of noninflamed tissue cage fluid (transudate; $1.5 \mathrm{~mL}$ ).

\section{Sampling procedures}

Blood samples $(10 \mathrm{~mL})$ were collected from a jugular vein, into monovettes (Sarstedt, Leicester, UK) without anticoagulant at times of 5, 10, 15, 20, 30 and $45 \mathrm{~min}$ and 1, 1.5, 2, 3, 4, 6, 9, $12,24,30,36,48$ and $72 \mathrm{~h}$ after administration of drugs. Serum was harvested after centrifugation $(2000 \boldsymbol{g}$ for $10 \mathrm{~min}$ at $4{ }^{\circ} \mathrm{C}$ ) and aliquoted into two polypropylene tubes. Samples were stored at $-20{ }^{\circ} \mathrm{C}$ until either assayed for $\mathrm{MB}$ concentration or for measurement of $e x$ vivo antibacterial activity of $\mathrm{MB}$.

Exudate and transudate samples were collected at the following times: $0,1,3,6,9,12,24,30,36,48$ and $72 \mathrm{~h}$ and centrifuged at $2000 \mathrm{~g}$ for $10 \mathrm{~min}$ at $4{ }^{\circ} \mathrm{C}$ to remove cells. Supernatants were divided into two aliquots and stored at $-20{ }^{\circ} \mathrm{C}$ until either analysed for MB concentration or measurement of $e x$ vivo antibacterial activity of $\mathrm{MB}$.

\section{Analysis of $M B$}

Serum, exudate and transudate samples were assayed for MB by a high performance liquid chromatography (HPLC-Waters 600E; Milford, Boston, MA, USA) method with fluorescence detection as described by Petracca et al. (1993), with minor modifications as described by Aliabadi and Lees (2002). The precolumn and column (Toso Haas, Linton, Cambridge, UK) used were Lichrosorb $\mathrm{RPC}_{18} 5 \mu \mathrm{m}$ and Lichrosorb $\mathrm{RPC}_{18} 7 \mu \mathrm{m}(250 \times 4 \mathrm{~mm})$, respectively, with fluorescence detection. Reagents were obtained from Sigma-Aldrich Chemicals Ltd (Poole, Dorset, UK).

Retention times for $\mathrm{MB}$ and internal standard were approximately 8 and $10 \mathrm{~min}$, respectively. The lower limit of quantification (LLOQ) of MB in serum, exudate and transudate was $0.005 \mu \mathrm{g} / \mathrm{mL}$. Control serum, exudate and transudate collected from the animals which had received no drug treatment were spiked with pure MB to prepare standards, ranging from 0.0025 to $5 \mu \mathrm{g} / \mathrm{mL}$. Linearity of the standard curve was $r^{2}>0.999$. In the MB assay, there was no interference from TA, and the percentage recovery of $\mathrm{MB}$ was $95.2 \pm 3.87$ (mean \pm SEM, $n=16$ ). The intra-assay and interassay repeatability and reproducibility of the method were evaluated using spiked concentrations. Intra-assay and interassay coefficients of variation $(\mathrm{CV} \%)$ were $2.42 \%$ and $5.90 \%$, respectively, at a concentration of $5 \mu \mathrm{g} / \mathrm{mL}$ and $7.65 \%$ and $12.5 \%$ at a concentration of $0.05 \mu \mathrm{g} / \mathrm{mL}$. Percentage accuracies and precision were $93.4 \%$ and $5.2 \%$ in the absence of TA and $91.4 \%$ and $3.6 \%$ in the presence of TA.

\section{Determination of $\mathrm{MIC}$ and $\mathrm{MBC}$}

For the determination of minimum inhibitory concentration (MIC) and minimum bactericidal concentration (MBC) of MB, clinical calf United Kingdom isolate M. haemolytica 3575 was grown freshly from beads stored at $-70{ }^{\circ} \mathrm{C}$ on tryptone soya blood agar (TSA; Oxoid, Basingstoke, UK). Eight to ten colonies were used to inoculate $30 \mathrm{~mL}$ of Mueller-Hinton broth (MHB), followed by incubation at $37^{\circ} \mathrm{C}$ on a shaking incubator $(220 \mathrm{rpm}$ ) for $3 \mathrm{~h}$ (final cell count approximately 
$\left.1.0 \times 10^{6} \mathrm{cfu} / \mathrm{mL}\right)$. Further details of the method are described in Aliabadi and Lees (2002).

In vitro and ex vivo antimicrobial activity of $M B$

The isolate of M. haemolytica 3575 was grown freshly from beads stored at $-70{ }^{\circ} \mathrm{C}$ on TSA. Eight to ten colonies were used to inoculate $9 \mathrm{~mL}$ of $\mathrm{MHB}$, and the culture was allowed to grow overnight at $37{ }^{\circ} \mathrm{C}$. In vitro time-kill curves were determined for $\mathrm{MB}$ in calf serum using multiples (0.25-8 times) of MIC. Ex vivo bacterial time-kill curves were determined in serum, exudate and transudate samples as described by Aliabadi and Lees (2002). The limit of detection was $10 \mathrm{cfu} / \mathrm{mL}$

\section{PK analyses}

Marbofloxacin concentration-time data in serum, exudate and transudate for individual calves were analysed using WinNonlin programmes (Pharsight Corporation, Mountain View, CA, USA). Serum data were submitted to compartmental analysis using nonlinear least squares regression. Schwarz criteria and Minimum Akaike Information Criteria Estimates were applied to discriminate the best fitting model and improved fit of data was achieved by re-weighting.

\section{PK-PD integration and PK-PD modelling}

For PK-PD integration, the surrogates $C_{\max } / \mathrm{MIC}$ and $\mathrm{AUC}_{24 \mathrm{~h}}$ / MIC were calculated for each fluid (serum, exudate and transudate) for each animal. Results were expressed as mean \pm SEM. For PK-PD modelling, $\mathrm{AUC}_{24} \mathrm{~h} / \mathrm{MIC}$ data from ex vivo bacterial growth inhibition curves were modelled to the Sigmoidal E-max equation:

$$
E=E_{0}+\frac{E_{\max } \times C_{e}^{N}}{\mathrm{EC}_{50}^{N}+C_{e}^{N}}
$$

where $E_{0}$ is the change in $\log _{10} \mathrm{cfu} / \mathrm{mL}$ of sample (in serum, exudate or transudate) after 24-h incubation in the control sample (absence of $\mathrm{MB}$ ) compared with the initial inoculum $\log _{10}$ $\mathrm{cfu} / \mathrm{mL}, \mathrm{E}_{\text {max }}$ is the maximum antibacterial effect determined as difference in $\log _{10} \mathrm{cfu} / \mathrm{mL}$ in samples incubated with $\mathrm{MB}$ between time 0 and $24 \mathrm{~h}$ when the detection limit $(10 \mathrm{cfu} / \mathrm{mL})$ is reached, $C_{\mathrm{e}}$ is the $\mathrm{AUC}_{24 \mathrm{~h}} / \mathrm{MIC}$ in the effect compartment (ex vivo site), $\mathrm{EC}_{50}$ is the $\mathrm{AUC}_{24 \mathrm{~h}} / \mathrm{MIC}$ value producing a $50 \%$ reduction in bacterial count from the initial $\log _{10} \mathrm{cfu} / \mathrm{mL}$, and $N$ is the Hill coefficient that describes the steepness of the $\mathrm{AUC}_{24 \mathrm{~h}}$ /MIC-effect curve. These PD parameters were calculated using the nonlinear WinNonlin regression programme (Pharsight Corporation).

The antibacterial effect of MB was quantified for three levels of growth inhibition by calculation of $\mathrm{AUC}_{24} \mathrm{~h} / \mathrm{MIC}$ for bacteriostatic action, bactericidal action and bacterial eradication. $\mathrm{AUC}_{24 \mathrm{~h}} / \mathrm{MIC}$ values for bacteriostatic and bactericidal actions were defined as those values that produced $E=0$ (no change in bacterial count after 24-h incubation) and $\mathrm{AUC}_{24 \mathrm{~h}} / \mathrm{MIC}=-3$ (a $3 \log$ or $99.9 \%$ reduction of the original inoculum count after 24-h incubation), respectively. $\mathrm{AUC}_{24 \mathrm{~h}} / \mathrm{MIC}$ for bacterial eradication was defined as the lowest $\mathrm{AUC}_{24 \mathrm{~h}} / \mathrm{MIC}$ that provided a 4-log reduction in bacterial count of original inoculum.

\section{Statistical analyses}

All data are presented as mean \pm SEM. Differences between animals, times, sequence and cross-over periods and their associated two-factor interactions were analysed by analysis of variance analysis (ANOVA). For PD measurements, the significance of differences at each time point between treatment groups and between pretreatment and post-treatment values was further investigated using Fisher's multiple comparisons test. For PK variables, the significance of differences between $\mathrm{MB}$ and $\mathrm{MB}+\mathrm{TA}$ was assessed using the Mann-Whitney test. All tests of significance were carried out at a $5 \%$ probability level.

\section{RESULTS}

Pharmacokinetics of $M B$

Serum. Serum concentration-time data for $\mathrm{MB}$ and $\mathrm{MB}+\mathrm{TA}$ are presented in Figs 1 and 2, respectively. The data provided a best fit to a mono-compartment model with a first-order absorption phase in 13 of 16 calves. The data from three

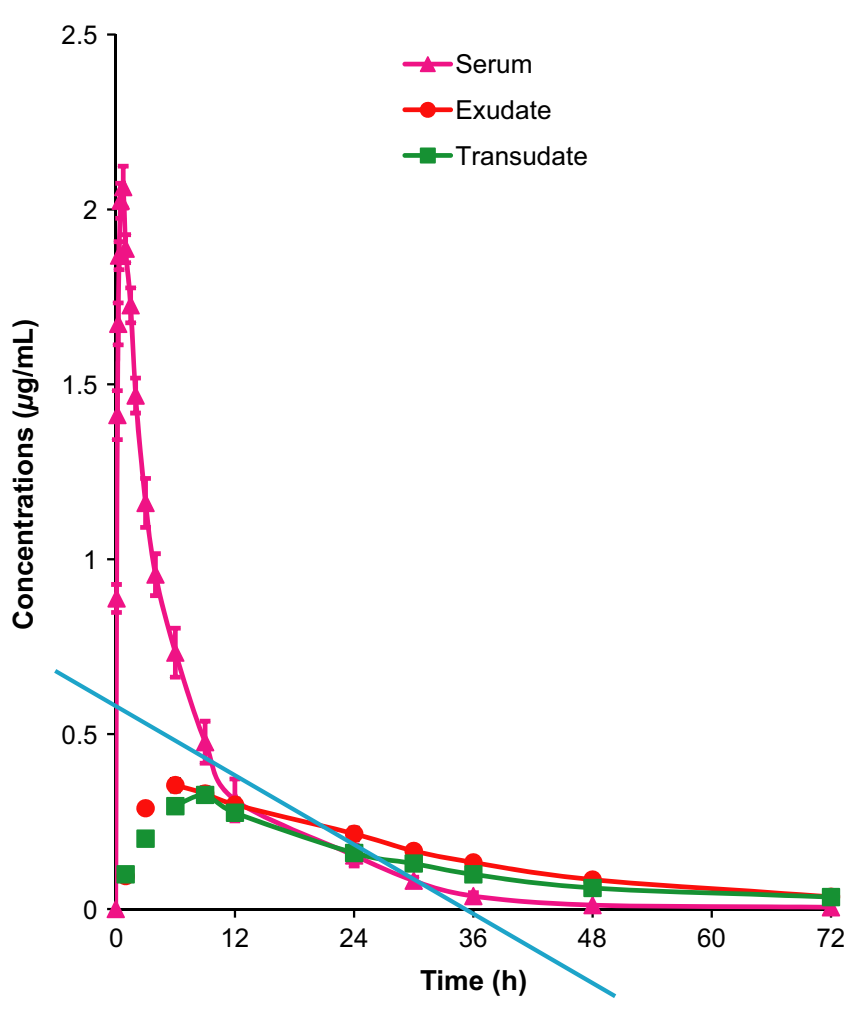

Fig. 1. Arithmetic plot of marbofloxacin (MB) concentration in serum $(\triangle)$, exudate (๑) and transudate ( $\square$ ) after intramuscular administration of MB. Values are mean \pm SEM $(n=8)$. 


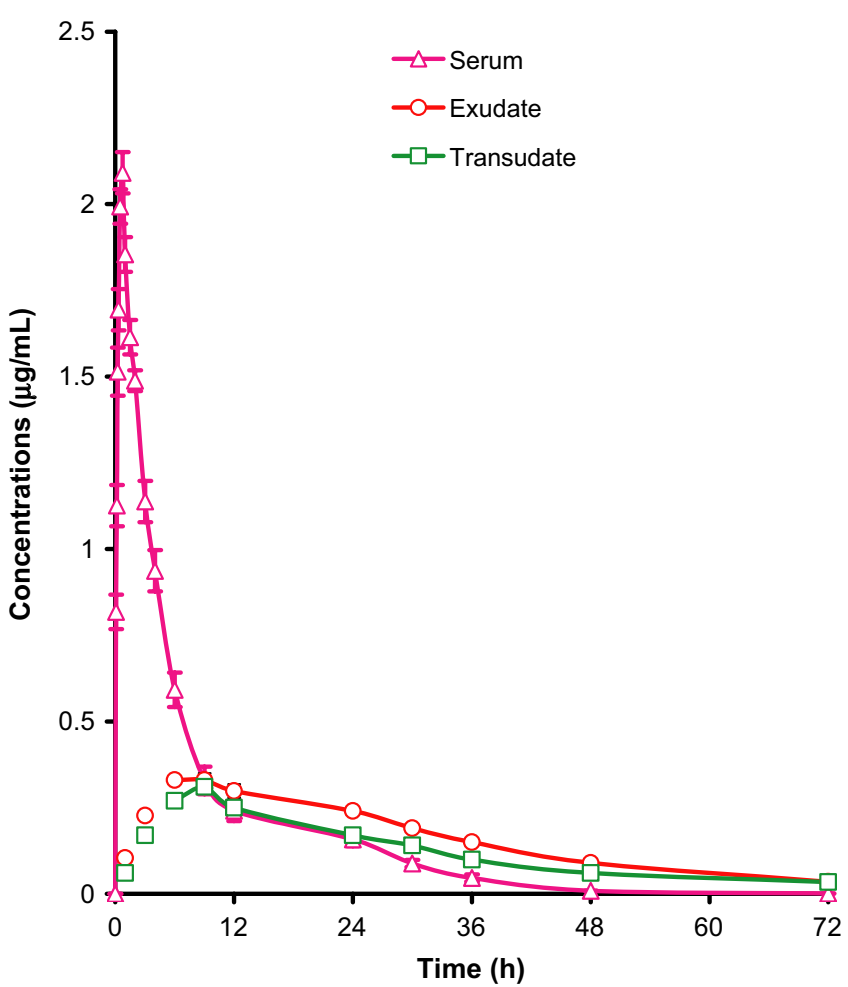

Fig. 2. Arithmetic plot of marbofloxacin (MB) concentration in serum $(\triangle)$, exudate $(\bigcirc)$ and transudate $(\square)$ after intramuscular administration of MB + TA. Values are mean $\pm \operatorname{SEM}(n=8)$.

animals (one calf after $\mathrm{MB}$ and two calves after $\mathrm{MB}+\mathrm{TA}$ ) gave best fit to a two-compartment model. PK parameters were calculated using a one-compartment model for consistency. Following MB administration, the absorption of MB was rapid $\left(t_{1 / 2 \mathrm{abs}}=0.14 \mathrm{~h}\right)$. Mean elimination half-life was $5.24 \mathrm{~h}$. Other variables are presented in Table 1 . In calves receiving $\mathrm{MB}+\mathrm{TA}$, there were no significant differences from $\mathrm{MB}$ administration (Table 1).

Tissue cage fluids. Exudate and transudate drug concentrationtime profiles are illustrated in Fig. 1 for MB and Fig. 2 for $\mathrm{MB}+\mathrm{TA}$. For both $\mathrm{MB}$ and $\mathrm{MB}+\mathrm{TA}$ administrations, exudate and transudate MB concentrations exceeded LLOQ at $1 \mathrm{~h}$ and were lower than serum levels up to $12 \mathrm{~h}$ but then exceeded those in serum from 12 to $72 \mathrm{~h}$ (Figs 1 \& 2). MB concentrations exceeded LLOQ up to $72 \mathrm{~h}$. The data fitted a one-compartment model.

Penetration of $\mathrm{MB}$ into exudate was relatively rapid but somewhat slower for transudate, as indicated by the values of $t_{1 / 2 \text { pen }}$ of 2.11 and $3.33 \mathrm{~h}$, respectively (Table 2). Mean AUC values for exudate $(12.1 \mu \mathrm{g} \cdot \mathrm{h} / \mathrm{mL})$ and transudate (9.6 $\mu \mathrm{g} \cdot \mathrm{h} / \mathrm{mL})$ for $\mathrm{MB}$ were similar but somewhat lower than serum $(15.1 \mu \mathrm{g} \cdot \mathrm{h} / \mathrm{mL})$. The slower elimination of MB from tissue cage fluids compared with serum was indicated by mean $t_{1 / 2 \mathrm{el}}$ values of 18.1-19.1 $\mathrm{h}$ for exudate and 13.7-14.5 $\mathrm{h}$ for transudate, compared with $5.24-5.69 \mathrm{~h}$ for serum $(P<0.01)$. Longer persistence of drug in exudate and transudate compared with
Table 1. Pharmacokinetic parameters for marbofloxacin (MB) in serum after intramuscular administration of $\mathrm{MB}$ and $\mathrm{MB}+\mathrm{TA}$ at the dose of $2 \mathrm{mg} / \mathrm{kg}$ (mean and SEM, $n=8$ ): compartmental modelling

\begin{tabular}{|c|c|c|c|c|}
\hline \multirow[b]{2}{*}{ Parameter (units) } & \multicolumn{2}{|c|}{ MB } & \multicolumn{2}{|c|}{$\mathrm{MB}+\mathrm{TA}$} \\
\hline & $\begin{array}{c}\text { Arithmetic } \\
\text { mean }\end{array}$ & SEM & $\begin{array}{c}\text { Arithmetic } \\
\text { mean }\end{array}$ & SEM \\
\hline $\mathrm{k}_{\mathrm{abs}}($ per h) & 8.44 & 0.61 & 7.06 & 0.47 \\
\hline $\mathrm{k}_{\mathrm{el}}($ per h) & 0.15 & 0.02 & 0.12 & 0.01 \\
\hline$t_{1 / 2 \mathrm{abs}}(\mathrm{h})$ & 0.14 & 0.05 & 0.10 & 0.01 \\
\hline$t_{1 / 2 \mathrm{el}}(\mathrm{h})$ & 5.24 & 0.59 & 5.69 & 0.23 \\
\hline $\mathrm{MRT}_{\text {O-last }}(\mathrm{h})$ & 8.61 & 0.06 & 9.17 & 0.27 \\
\hline$C_{\max }(\mu \mathrm{g} / \mathrm{mL})$ & 1.84 & 0.11 & 1.70 & 0.05 \\
\hline$T_{\max }(\mathrm{h})$ & 0.63 & 12 & 0.60 & 0.03 \\
\hline $\operatorname{AUC}_{0-\infty}(\mu \mathrm{g} \cdot \mathrm{h} / \mathrm{mL})$ & 15.1 & 1.3 & 15.1 & 1.0 \\
\hline $\mathrm{AUC}_{0-24}(\mu \mathrm{g} \cdot \mathrm{h} / \mathrm{mL})$ & 14.0 & 0.06 & 12.6 & 0.7 \\
\hline$V(\mathrm{~d})_{\text {area }} / F(\mathrm{~L} / \mathrm{kg})$ & 0.99 & 0.011 & 1.10 & 0.030 \\
\hline $\mathrm{CI}_{\mathrm{B}} / F(\mathrm{~L} \cdot \mathrm{kg} / \mathrm{h})$ & 0.138 & & 0.136 & 0.008 \\
\hline
\end{tabular}

Pharmacokinetic parameters were calculated using a one-compartment model with first-order input and output: $\mathrm{k}_{\mathrm{abs}}=$ absorption rate constant; $\mathrm{k}_{\mathrm{el}}=$ elimination rate constant; $t_{1 / 2 \mathrm{abs}}=$ absorption half-life; $t_{1 / 2 \mathrm{el}}=$ elimination half-life; $C_{\max }=$ maximum concentration; $T_{\max }=$ time to achieve maximum concentration; $\mathrm{AUC}_{0-\infty}=$ area under plasma concentrationtime curve to infinity; $\mathrm{AUC}_{0-24}=$ area under plasma concentration-time curve to sampling time of $24 \mathrm{~h} ; V(\mathrm{~d})_{\text {area }} / F=$ volume of distribution scaled to bioavailability; $\mathrm{CI}_{\mathrm{B}} / F=$ clearance scaled to bioavailability. There were no significant differences between $\mathrm{MB}$ and $\mathrm{MB}+\mathrm{TA}$.

serum $(P<0.01)$ was further indicated by MRT values (Tables 1 and 2). There were no significant differences between $\mathrm{MB}$ and $\mathrm{MB}+\mathrm{TA}$ for either exudate or transudate.

\section{Pharmacodynamics, $P K-P D$ integration and $P K-P D$ modelling}

In vitro MIC and $M B C$ and time-kill data and integration with in vivo PK data. The MICs of MB against M. haemolytica 3575 for the four fluids, MHB, serum, exudate and transudate, are presented in Table 3, together with integrated PK-PD indices derived from in vivo $\mathrm{PK}$ data and in vitro $\mathrm{MIC}$ values. MBC values were only moderately greater than MIC values. Both $C_{\max } / \mathrm{MIC}$ and $\mathrm{AUC}_{24 \mathrm{~h}} / \mathrm{MIC}$ ratios indicated that serum concentrations of $\mathrm{MB}$ would be expected to have a high level of activity against this strain of M. haemolytica. The in vitro time-kill curves in serum for eight multiples of MIC (0.25-8) indicate a concentrationdependent killing action of MB (Fig. 3). At $2 \times$ MIC bacterial count was reduced $<10 \mathrm{cfu} / \mathrm{mL}$ at $4 \mathrm{~h}$ and at $3 \times \mathrm{MIC}$ and higher, the count was reduced to $<10 \mathrm{cfu} / \mathrm{mL}$ at $2 \mathrm{~h}$. The initial bacterial count ranged from 6.0 to $6.9 \times 10^{6} \mathrm{cfu} / \mathrm{mL}$.

As mean exudate and transudate $\mathrm{MB}$ concentrations exceeded the MIC concentrations of 0.045 and $0.040 \mu \mathrm{g} / \mathrm{mL}$ for $48 \mathrm{~h}$, respectively, and in some animals at $72 \mathrm{~h}$, it is relevant to consider average concentrations $\left(C_{\mathrm{av}}\right)$ over each of the time periods $0-24,24-48$ and 48-72 h, relative to MICs (Table 4). For both exudate and transudate, and $\mathrm{MB}$ and $\mathrm{MB}+\mathrm{TA}$, $C_{\text {av }} /$ MIC was $>1$ over each of the periods $0-24,24-48$ and $48-$ $72 \mathrm{~h}$. 
Table 2. Pharmacokinetic parameters for marbofloxacin (MB) in exudate and transudate after intramuscular administration of $\mathrm{MB}$ and $\mathrm{MB}+\mathrm{TA}$ at the dose of $2 \mathrm{mg} / \mathrm{kg}$ (mean and SEM, $n=8$ ): compartmental modelling

\begin{tabular}{|c|c|c|c|c|c|c|c|c|}
\hline \multirow[b]{2}{*}{ Parameters (units) } & \multicolumn{4}{|c|}{ Exudate } & \multicolumn{4}{|c|}{ Transudate } \\
\hline & Arithmetic mean & SEM & Arithmetic mean & SEM & Arithmetic mean & SEM & Arithmetic mean & SEM \\
\hline $\operatorname{AUC}_{0-\infty}(\mu \mathrm{g} \cdot \mathrm{h} / \mathrm{mL})$ & 12.1 & 0.9 & 13.0 & 0.5 & 9.6 & 0.9 & 9.2 & 0.5 \\
\hline$C_{\max }(\mu \mathrm{g} / \mathrm{mL})$ & 0.35 & 0.01 & 0.34 & 0.02 & 0.31 & 0.02 & 0.28 & 0.01 \\
\hline$T_{\max }(\mathrm{h})$ & 7.24 & 0.82 & 9.37 & 0.71 & 8.82 & 0.82 & 9.25 & 0.49 \\
\hline $\mathrm{MRT}_{\text {(0-last) }}(\mathrm{h})$ & 23.6 & 0.7 & 24.8 & 0.3 & 22.6 & 1.2 & 23.5 & 0.7 \\
\hline
\end{tabular}

Pharmacokinetic parameters were calculated using a one-compartment model with first-order input and output: $t_{1 / 2 p e n}=$ penetration half-life; $t_{1 / 2 \mathrm{el}}=$ elimination half-life; $C_{\max }=$ maximum concentration; $T_{\max }=$ time to achieve maximum concentration; $\mathrm{AUC}_{0-\infty}=\operatorname{area}_{\mathrm{under}}$ exudate/transudate concentration-time curve; $\mathrm{MRT}_{0 \text {-last }}=$ mean residence time to last sampling time. There were no statistically significant differences between exudate and transudate and no significant differences between $\mathrm{MB}$ and $\mathrm{MB}+\mathrm{TA}$.

Table 3. MIC and MBC values* in four matrices and surrogate markers derived by PK-PD integration ${ }^{\dagger}$ for Mannheimia haemolytica strain 3575

\begin{tabular}{|c|c|c|c|c|c|c|}
\hline \multirow[b]{2}{*}{ Matrix } & \multirow{2}{*}{$\begin{array}{c}\text { MIC } \\
(\mu \mathrm{g} / \mathrm{mL})\end{array}$} & \multirow{2}{*}{$\begin{array}{c}\mathrm{MBC} \\
(\mu \mathrm{g} / \mathrm{mL})\end{array}$} & \multicolumn{2}{|c|}{$C_{\max } / \mathrm{MIC}$} & \multicolumn{2}{|c|}{$\begin{array}{c}\mathrm{AUC}_{24 \mathrm{~h}} / \mathrm{MIC} \\
\text { (h) }\end{array}$} \\
\hline & & & $\mathrm{MB}$ & $\mathrm{MB}+\mathrm{TA}$ & $\mathrm{MB}$ & $\mathrm{MB}+\mathrm{TA}$ \\
\hline MHB & 0.040 & 0.055 & - & - & - & - \\
\hline Serum & 0.040 & 0.060 & $46.1: 1$ & $42.6: 1$ & 350 & 316 \\
\hline Exudate & 0.045 & 0.060 & 7.83:1 & 7.45:1 & 142 & 140 \\
\hline Transudate & 0.040 & 0.060 & $7.85: 1$ & 7.09:1 & 140 & 129 \\
\hline
\end{tabular}

MHB, Mueller-Hinton broth.

* $\mathrm{MIC}$ and $\mathrm{MBC}$ determined in vitro; ${ }^{\dagger} \mathrm{C}_{\max }$ and $\mathrm{AUC}_{24 \mathrm{~h}}$ determined in vivo.

Ex vivo antibacterial activity of $M B$ in serum. The ex vivo antibacterial time-kill curves for MB in serum against M. haemolytica 3575 are illustrated in Fig. 4a (MB) and Fig. 4b (MB + TA). Samples collected up to 9-12 h after drug administration reduced bacterial counts to $<10 \mathrm{cfu} / \mathrm{mL}$ after $6-\mathrm{h}$ incubation. The $24 \mathrm{~h}$ samples were bactericidal and 36-h samples were bacteriostatic. There was no regrowth between 6 and $24 \mathrm{~h}$ incubation times.
Ex vivo antibacterial activity of $M B$ in exudate and transudate. The ex vivo antibacterial time-kill curves for $\mathrm{MB}$ in exudate and transudate are illustrated in Figs 5 and 6, respectively. In all exudate samples collected up to $24 \mathrm{~h}$ after dosing with $\mathrm{MB}$ (Fig. 5a) and $30 \mathrm{~h}$ after $\mathrm{MB}+\mathrm{TA}$ (Fig. 5b), bacterial count was reduced to $<10 \mathrm{cfu} / \mathrm{mL}$ after $6 \mathrm{~h}$ incubation. For both $\mathrm{MB}$ and $\mathrm{MB}+\mathrm{TA}, 36 \mathrm{~h}$ samples produced a 2-log reduction in bacterial count. There was no regrowth between 6 and $24 \mathrm{~h}$ incubation times. Growth inhibition in transudate samples was similar to that in exudate samples (Fig. 6a, b), except that the lower concentrations of $\mathrm{MB}$ at late sampling times (30, 36 and $48 \mathrm{~h}$ ) produced correspondingly less growth inhibition.

PK-PD modelling of ex vivo data. PK-PD modelled data for serum are presented in Table 5. Values of $\mathrm{AUC}_{24 \mathrm{~h}} / \mathrm{MIC}$ for bacteriostatic action were 18.3 and $20.1 \mathrm{~h}$ for $\mathrm{MB}$ and $\mathrm{MB}+\mathrm{TA}$, respectively. Higher exposure levels were required for bactericidal and eradication levels of activity. The data in Table 6 indicate that the multiples of MIC required for bacteriostatic, bactericidal and eradication levels were $0.76,3.8$ and 5.8,

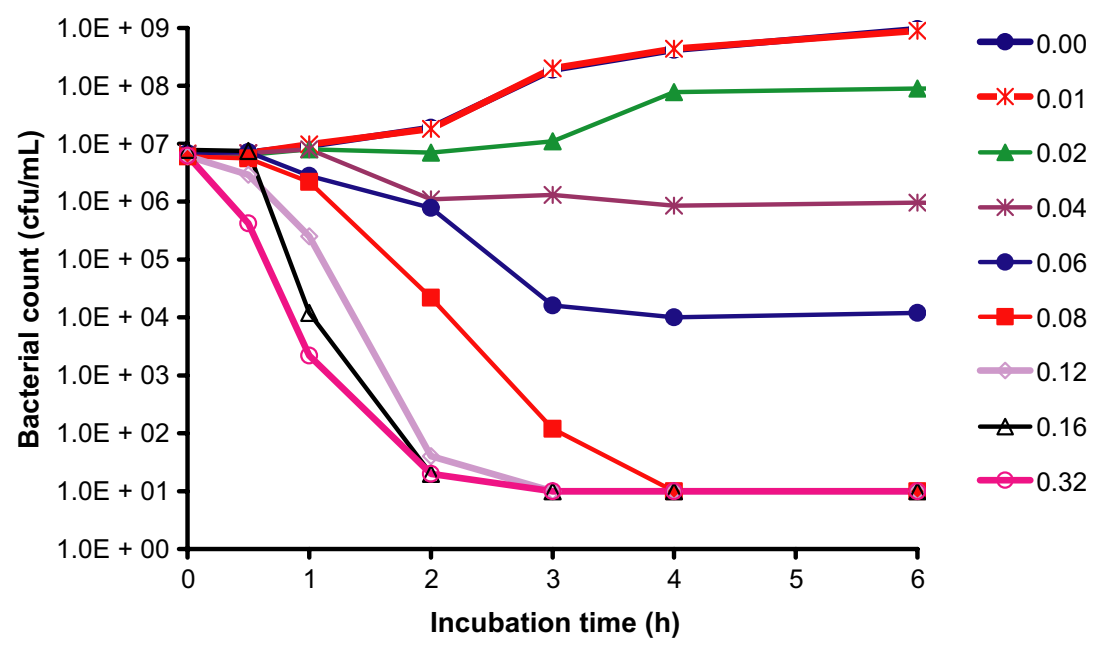

Fig. 3. In vitro time-kill curves for marbofloxacin (concentration range $0.0-0.32$ $\mu \mathrm{g} / \mathrm{mL}$ ) against Mannheimia haemolytica 3575 in calf serum. 
Table 4. $C_{\mathrm{av}} / \mathrm{MIC}^{*}$ ratios for serum, exudate and transudate over three 24-h time periods for marbofloxacin (MB) and MB + TA against Mannheimia haemolytica strain 3575

\begin{tabular}{|c|c|c|c|c|c|c|}
\hline \multirow[b]{3}{*}{ Matrix } & \multicolumn{6}{|c|}{$C_{\mathrm{av}} / \mathrm{MIC}$} \\
\hline & \multicolumn{2}{|c|}{$0-24 \mathrm{~h}$} & \multicolumn{2}{|c|}{ 24-48 h } & \multicolumn{2}{|c|}{$48-72 \mathrm{~h}$} \\
\hline & MB & $\mathrm{MB}+\mathrm{TA}$ & MB & $\mathrm{MB}+\mathrm{TA}$ & MB & $\mathrm{MB}+\mathrm{TA}$ \\
\hline Serum & $13.5: 1$ & $12.2: 1$ & $1.24: 1$ & $1.51: 1$ & $0.08: 1$ & $0.11: 1$ \\
\hline Exudate & $5.90: 1$ & $5.80: 1$ & $3.00: 1$ & $3.52: 1$ & $1.28: 1$ & 1.40:1 \\
\hline Transudate & $5.79: 1$ & 5.40:1 & $2.44: 1$ & 2.60:1 & $1.15: 1$ & $1.12: 1$ \\
\hline
\end{tabular}

${ }^{*} C_{\mathrm{av}}=$ average 24 -h concentration measured in vivo and MIC values determined in vitro.

respectively, for $\mathrm{MB}$ and $0.84,2.9$ and 4.4 , respectively, for $\mathrm{MB}+\mathrm{TA}$.

Values of $\mathrm{AUC}_{24} \mathrm{~h} / \mathrm{MIC}$ for bacteriostasis, bactericidal action and eradication were similar for $\mathrm{MB}$ alone and $\mathrm{MB}+\mathrm{TA}$ for exudate (Table 6; Fig. 7). For transudate also, $\mathrm{AUC}_{24 \mathrm{~h}} / \mathrm{MIC}$ mean values were similar for $\mathrm{MB}$ and $\mathrm{MB}+\mathrm{TA}$. Moreover, transudate and exudate $\mathrm{AUC}_{24} \mathrm{~h} / \mathrm{MIC}$ values were very similar. For both $\mathrm{MB}$ and $\mathrm{MB}+\mathrm{TA}$, the concentration-effect relationships were steeper for exudate and transudate than for serum.

\section{DISCUSSION}

\section{Pharmacokinetics}

The PK of MB administered i.m. or i.v in calves and adult cows has been investigated by previous workers (Thomas et al., 1994a,b; Schneider et al.,1996; Shem-Tov et al., 1997; Aliabadi \& Lees, 2002; Ismail \& El-Kattan, 2007). The latter workers compared healthy calves with those naturally infected with M. haemolytica, demonstrating significantly longer elimination $t_{1 / 2}$ and MRT in diseased calves. In the present study in healthy male calves of the Holstein Friesian breed, PK indices $\left(t_{1 / 2 \mathrm{abs}}, t_{1 / 2 \mathrm{el}}\right.$, AUC MRT and $C_{\text {max }}$ ) were similar to those previously reported in healthy male Friesian calves (Aliabadi \& Lees, 2002) and in cross-breed Simmental calves, gender not stated (Ismail \&
Fig. 4. Ex vivo inhibition of bacterial growth in serum before and after i.m. administration of (a) marbofloxacin $(\mathrm{MB})$ and (b) $\mathrm{MB}+\mathrm{TA}$ (sampling times of 1, 3, 6, 9, 12, 24, 30, 36 and $48 \mathrm{~h})$. Values are means $(n=8)$. SEM bars not included for clarity.
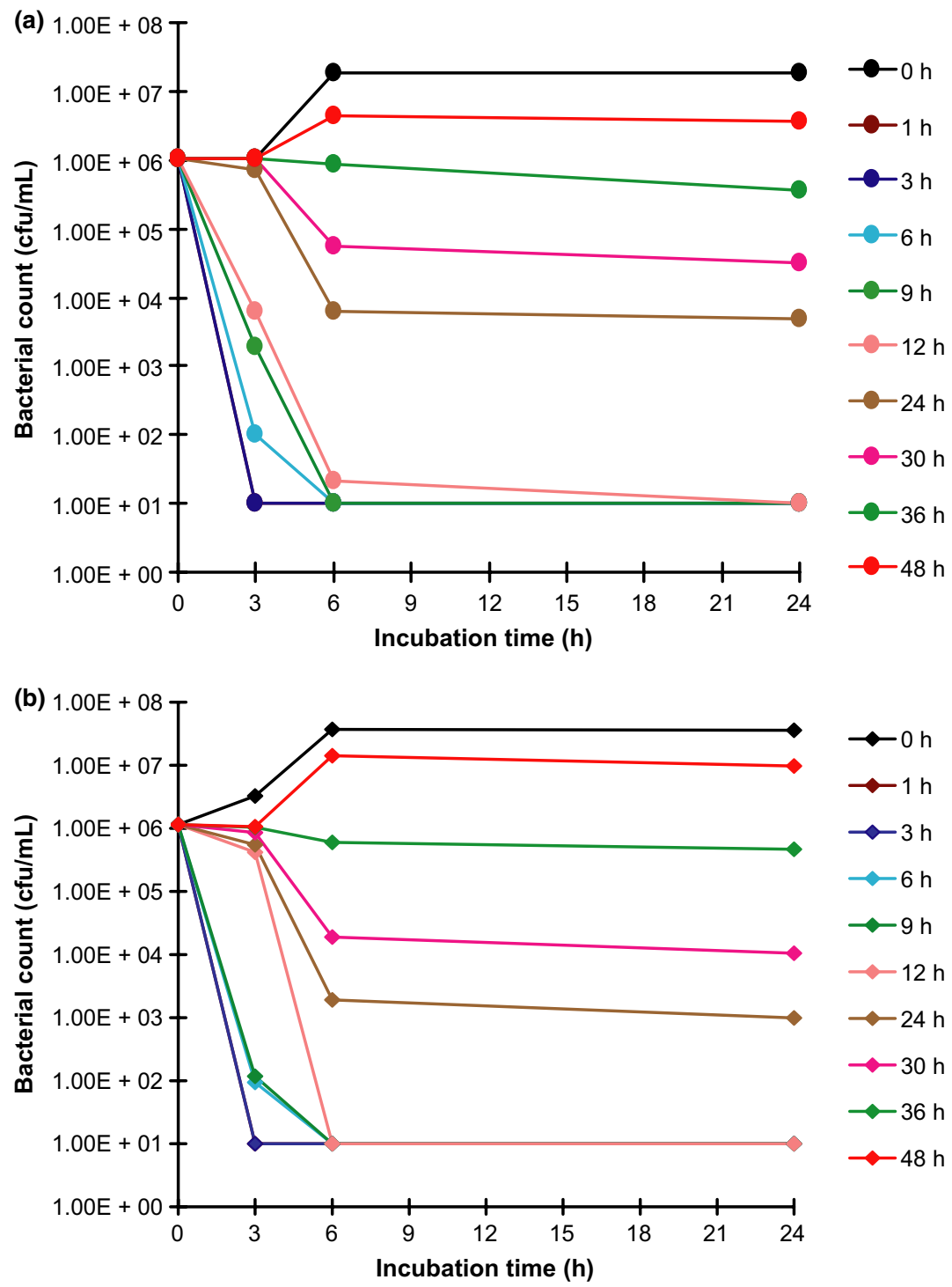

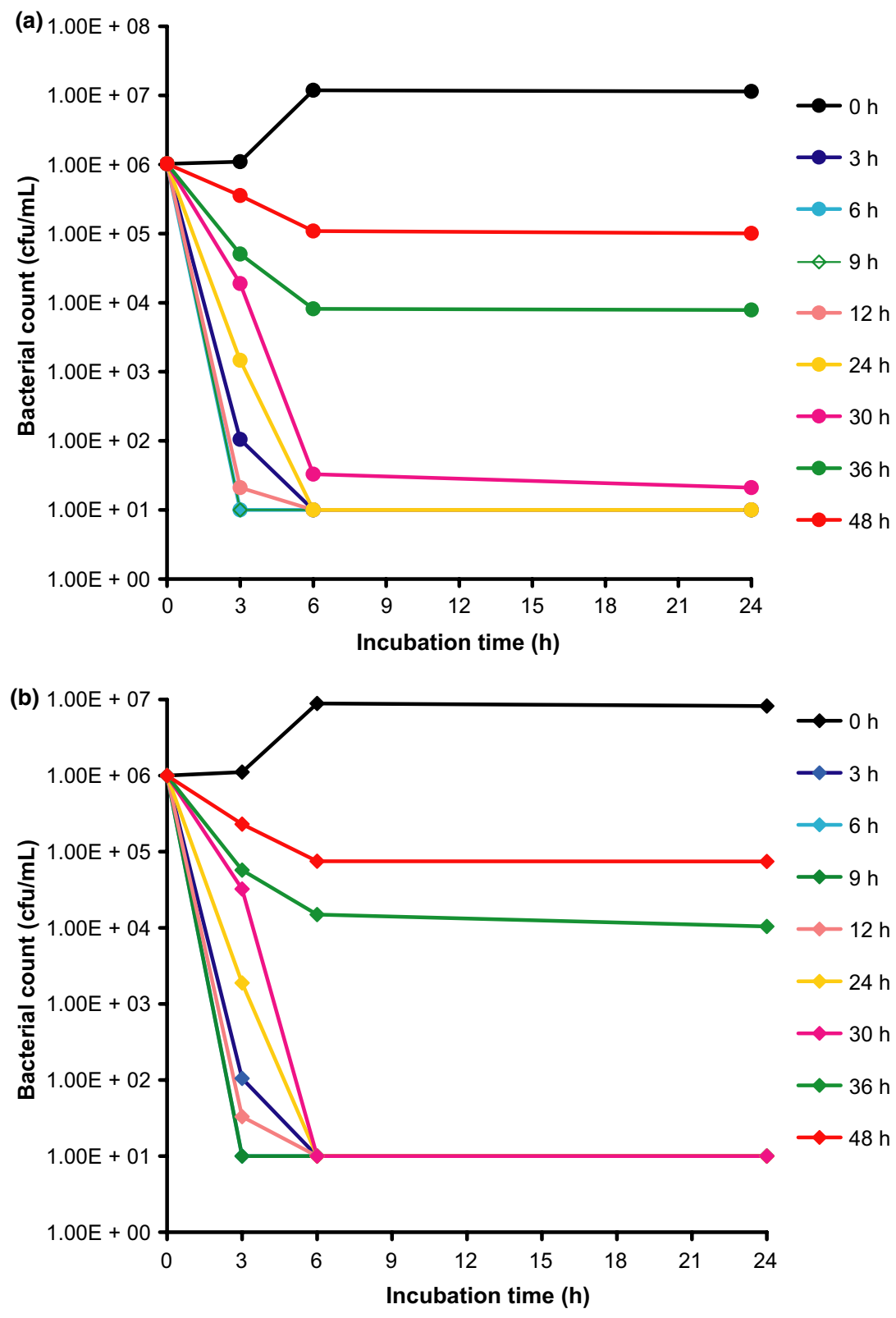

Fig. 5. Ex vivo inhibition of bacterial growth in exudate before and after i.m. administration of (a) marbofloxacin $(\mathrm{MB})$ and (b) $\mathrm{MB}+\mathrm{TA}$ (sampling times of $1,3,6,9,12,24,30$, 36 and 48 h). Values are mean $(n=8)$. SEM bars not included for clarity.
El-Kattan, 2007). Similar findings were reported for MB in adult lactating cattle (Shem-Tov et al., 1997).

In the present study the $\mathrm{PK}$ of $\mathrm{MB}$ after i.m. administration of $\mathrm{MB}$ and $\mathrm{MB}+\mathrm{TA}$ was best described by a one-compartment model with absorption phase. Moreover, all derived PK variables for $\mathrm{MB}$ were similar for administration of the drug alone and in combination with TA. This absence of influence of co-administered TA on the PK profile of MB is in contrast to the effect of MB on the PK of TA. Sidhu et al. (2005) reported in a calf study decreased $C_{\max }$ and AUC of TA in serum and exudate and decreased AUC in transudate in the presence of $\mathrm{MB}$.

The tissue cage model used in this study was developed by Higgins et al. (1984) and Sidhu et al. (2003). It is important to note that it is not a model which is the predictive of penetration of drugs into tissue interstitial fluid. However, it does give an indication of rates of drug penetration into and persistence in poorly vascularized tissues (Clarke, 1989). The shape and size of tissue cages affects the kinetics of drug disposition into and removal from cages, being dependent on surface area/volume ratio. Nevertheless, the model does allow comparisons to be made of penetration into inflamed and noninflamed sites. Peak MB concentrations in exudate and transudate in this study were similar and significantly lower than the peak serum concentration. Mean exudate/serum AUC ratios were 0.80:1 for MB and $0.87: 1$ for $\mathrm{MB}+\mathrm{TA}$. Corresponding transudate/serum ratios were $0.62: 1$ and $0.61: 1$, respectively. Values of MRT indicated significantly longer persistence of $\mathrm{MB}$ in tissue cage fluids than in serum. Similar findings for penetration of MB into tissue cage fluids of goats and sheep were reported previously by Sidhu et al. (2010a,b). 
Fig. 6. Ex vivo inhibition of bacterial growth in transudate before and after i.m. administration of (a) marbofloxacin (MB) and (b) $\mathrm{MB}+\mathrm{TA}$ (sampling times of 1, 3, 6, 9, 12, 24, 30, 36 and $48 \mathrm{~h}$ ). Values are means $(n=8)$. SEM bars not included for clarity.
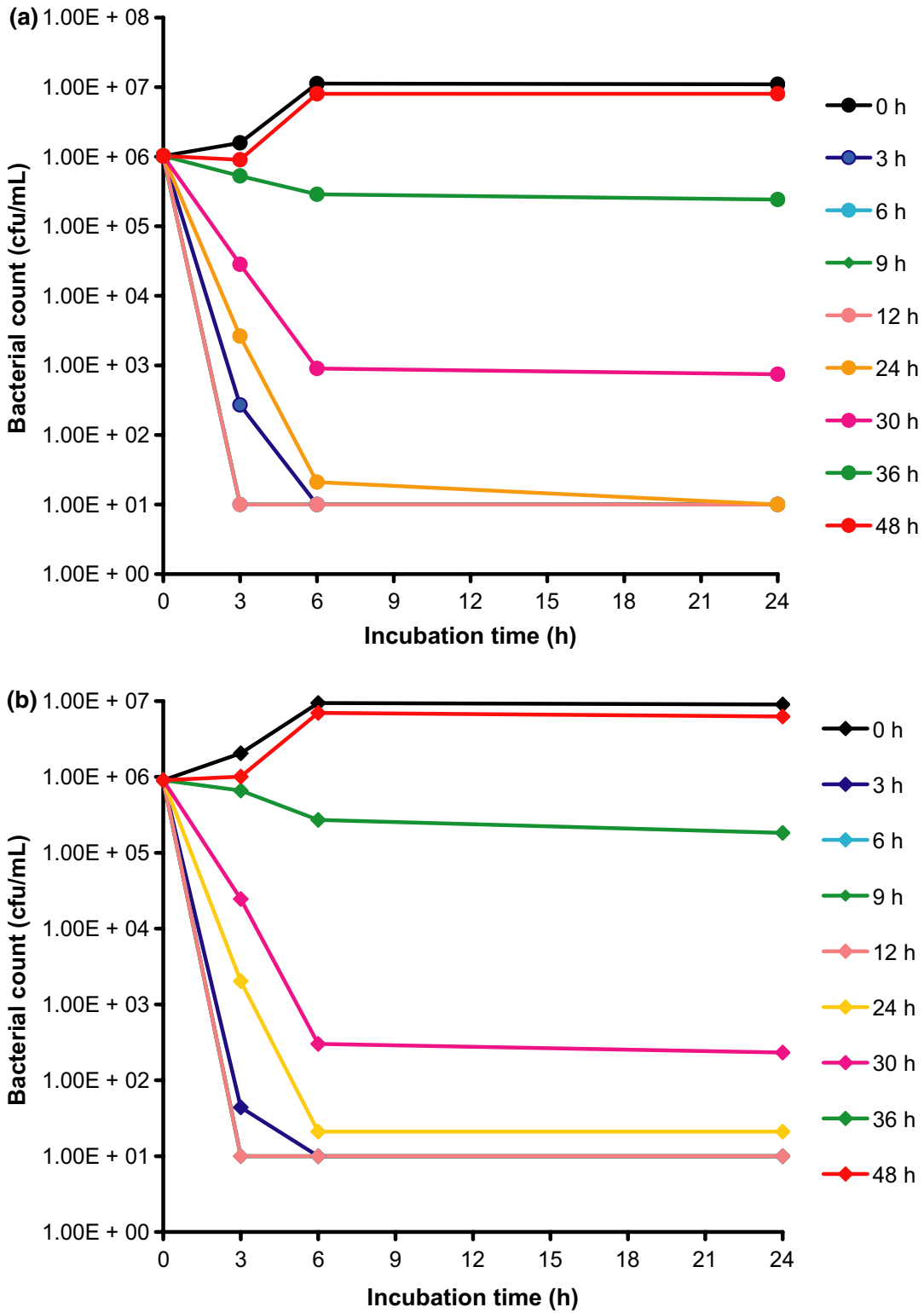

Table 5. PK-PD modelling of $e x$ vivo serum marbofloxacin data (mean \pm SEM, $n=8$ ) after intramuscular administration of marbofloxacin $(\mathrm{MB})$ and $\mathrm{MB}+\mathrm{TA}$

\begin{tabular}{|c|c|c|c|c|}
\hline \multirow[b]{2}{*}{ Parameter (units) } & \multicolumn{2}{|c|}{ MB } & \multicolumn{2}{|c|}{$\mathrm{MB}+\mathrm{TA}$} \\
\hline & Mean & SEM & Mean & SEM \\
\hline $\log E_{\mathrm{o}}(\mathrm{cfu} / \mathrm{mL})$ & 1.05 & 0.03 & 0.24 & 0.06 \\
\hline $\log E_{\max }(\mathrm{cfu} / \mathrm{mL})$ & -5.13 & 0.10 & -5.25 & 0.07 \\
\hline $\mathrm{AUC}_{24 \mathrm{~h}} / \mathrm{MIC}$ for bacteriostatic action (h) & 18.3 & 3.0 & 20.1 & 1.5 \\
\hline $\mathrm{AUC}_{24 \mathrm{~h}} / \mathrm{MIC}$ for bactericidal action (h) & 92 & 14 & 69 & 4 \\
\hline $\mathrm{AUC}_{24 \mathrm{~h}} / \mathrm{MIC}$ for bacterial eradication (h) & 139 & 25 & 106 & 11 \\
\hline Slope $(\mathrm{N})$ & 3.4 & 1.2 & 3.2 & 1.1 \\
\hline
\end{tabular}

$E_{\mathrm{o}}=$ difference in number of bacteria $(\mathrm{cfu} / \mathrm{mL})$ in control sample in absence of drugs between time 0 and $24 \mathrm{~h}$. $\mathrm{E}_{\max }=$ difference in number of bacteria $(\mathrm{cfu} / \mathrm{mL})$ in sample incubated with $\mathrm{MB}$ or $\mathrm{MB}+\mathrm{TA}$ between time 0 and $24 \mathrm{~h}$. $\mathrm{AUC}_{24 \mathrm{~h}} / \mathrm{MIC}$ values for bacteriostatic, bactericidal and eradication responses derived from the sigmoid $\mathrm{E}_{\max }$ curve. $\mathrm{N}=$ slope of $\mathrm{AUC}_{24 \mathrm{~h}}$ /MIC-response curve.

\section{Pharmacodynamics}

Plasma protein binding prevents the antimicrobial actions of antimicrobial drugs, and this was specifically demonstrated for the fluoroquinolones, moxifloxacin and trovafloxacin, in the investigation of Zeitlinger et al. (2008). However, in the present investigation MIC values for MB were the same in serum, transudate and MHB and only slightly higher in exudate. This is likely to reflect the low degree of protein binding of $\mathrm{MB}$ in calf serum. Ismail and El-Kattan (2007) reported percentage binding of $\mathrm{MB}$ to plasma protein of 29 and 27, respectively, in healthy and diseased calves, although a higher range of $58-69 \%$ was reported in adult cattle (Shem-Tov et al., 1997). However, there are other differences in composition (as well as protein content) between MHB and biological fluids, such as ion concentrations and $\mathrm{pH}$. It is therefore strongly preferable, as highlighted by Zeitlinger et al. (2008), to determine MICs, as the standard index 
Table 6. PK-PD modelling of ex vivo marbofloxacin data (mean \pm SEM, $n=8$ ) for exudate and transudate after intramuscular administration of marbofloxacin $(\mathrm{MB})$ and $\mathrm{MB}+\mathrm{TA}$

\begin{tabular}{|c|c|c|c|c|c|c|c|c|}
\hline \multirow[b]{3}{*}{ Parameter (units) } & \multicolumn{4}{|c|}{ Exudate } & \multicolumn{4}{|c|}{ Transudate } \\
\hline & \multicolumn{2}{|c|}{$\mathrm{MB}$} & \multicolumn{2}{|c|}{$\mathrm{MB}+\mathrm{TA}$} & \multicolumn{2}{|c|}{$\mathrm{MB}$} & \multicolumn{2}{|c|}{$\mathrm{MB}+\mathrm{TA}$} \\
\hline & Mean & SEM & Mean & SEM & Mean & SEM & Mean & SEM \\
\hline $\mathrm{AUC}_{24 \mathrm{~h}} / \mathrm{MIC}$ for bacteriostatic action (h) & 44 & 4 & 55 & 8 & 58 & 11 & 48 & 5.0 \\
\hline $\mathrm{AUC}_{24 \mathrm{~h}} / \mathrm{MIC}$ for bactericidal action $(\mathrm{h})$ & 77 & 4 & 69 & 8 & 77 & 10 & 66 & 5.0 \\
\hline $\mathrm{AUC}_{24 \mathrm{~h}} / \mathrm{MIC}$ for eradication (h) & 91 & 4 & 74 & 7 & 86 & 9 & 75 & 5.0 \\
\hline Slope $(\mathrm{N})$ & 7.4 & 1.4 & 19.4 & 4.3 & 10.4 & 2.5 & 11.5 & 4.47 \\
\hline
\end{tabular}

$\mathrm{AUC}_{24 \mathrm{~h}} / \mathrm{MIC}$ values for bacteriostatic, bactericidal and eradication responses derived from the sigmoid $\mathrm{E}_{\text {max }}$ curve. $\mathrm{N}=$ slope of $\mathrm{AUC} \mathrm{C}_{24} / \mathrm{MIC}-\mathrm{response}$ curve.

of drug efficacy and potency, in biological fluid matrices, when the objective of the study is the prediction of an effective dose for clinical use.

There was no regrowth when organisms were exposed to low MB concentrations either in vitro or ex vivo. Brown (1996) proposed that maximum concentrations of fluoroquinolones at the site of infection should be $>4-8$ times the in vitro determined MIC to minimize resistance development. The present in vitro data in serum and ex vivo data in serum, exudate and transudate demonstrated the virtual eradication of organisms by $\mathrm{MB}$ (reduced $\mathrm{cfu} / \mathrm{mL}$ to $<10$ ) at concentrations 4 times MIC and greater after 3 to $6 \mathrm{~h}$ exposure. Our data confirm previous reports that fluoroquinolones in general and $\mathrm{MB}$ in particular exert concentration-dependent killing of bacteria (Spreng et al., 1995; Aliabadi \& Lees, 2001, 2002; Sarasola et al., 2002; Aliabadi et al., 2003). The present study further demonstrates no interference in the antimicrobial action of $\mathrm{MB}$ in the presence of TA.

\section{$P K-P D$ integration of $M B$}

Optimizing dosage schedules of antimicrobial drugs is crucial in ensuring bacteriological and clinical cures and minimizing the emergence of resistance (Drusano, 2003; Lees et al., 2006; Fabrega et al., 2008). In veterinary medicine, approaches based

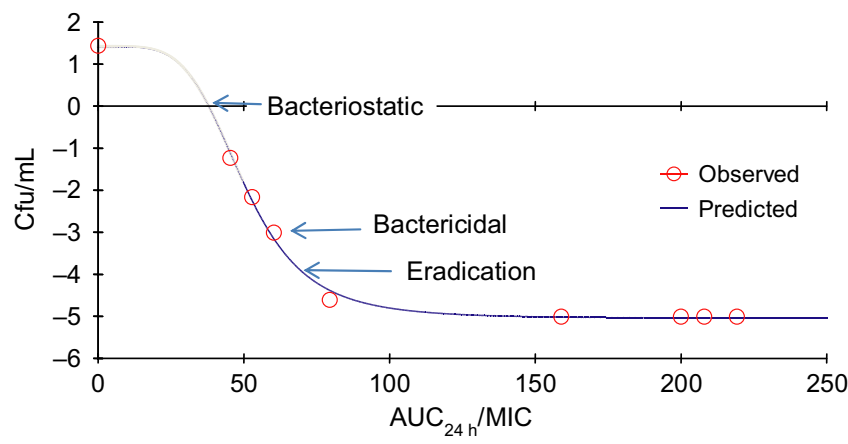

Fig. 7. A specimen plot of ex vivo $\mathrm{AUC}_{24 \mathrm{~h}} / \mathrm{MIC}$ versus bacterial count $(\log \mathrm{cfu} / \mathrm{mL})$ for Mannheimia haemolytica 3575 in calf exudate. Each point represents individual animal values. The curve is the line of best fit based on the Sigmoid E-max equation. on PK-PD integration and PK-PD modelling, using surrogate markers of clinical efficacy, have been applied to dosage determination for subsequent evaluation in clinical trials (Aliabadi \& Lees, 2001, 2002; Toutain, 2002, 2003a,b; Toutain \& Lees, 2004; Dova et al., 2006; Haritova et al., 2006). The surrogates most commonly used for fluoroquinolones relate maximum concentration in serum/plasma $\left(C_{\max }\right)$ and area under plasma/serum concentration-time curve (AUC) measured in vivo to $\mathrm{MIC}$ against pathogens determined in vitro, using the ratios $C_{\text {max }} / \mathrm{MIC}$ and $\mathrm{AUC} / \mathrm{MIC}$.

In early studies on ciprofloxacin, it was suggested that a $C_{\text {max }} / \mathrm{MIC}$ ratio of 10:1 and $\mathrm{AUC} / \mathrm{MIC}$ ratio of $125 \mathrm{~h}$ or greater predict a successful clinical outcome (Forrest et al., 1993; Sullivan et al., 1993). Similar or higher values have been proposed for all fluoroquinolones for avoidance of the emergence of resistance. In this study, $C_{\max } / \mathrm{MIC}$ and $\mathrm{AUC}_{24 \mathrm{~h}} / \mathrm{MIC}$ ratios for $\mathrm{MB}$ were $46.1: 1$ and $350 \mathrm{~h}$, respectively, for serum. Similar values were reported in a previous study on $\mathrm{MB}$ in calves (Aliabadi \& Lees, 2002). However, Drugeon et al. (1997) reported $\mathrm{MIC}_{50}$ and $\mathrm{MIC}_{90}$ values of 0.024 and $0.17 \mu \mathrm{g} / \mathrm{mL}$ for $\mathrm{MB}$ against 120 bovine strains of $M$. haemolytica. For $\mathrm{MIC}_{90}$, the integrated $C_{\text {max }} / \mathrm{MIC}$ and $\mathrm{AUC}_{24} \mathrm{~h} / \mathrm{MIC}$ ratios are 10.8:1 and $82 \mathrm{~h}$, respectively. On these data, $\mathrm{MB}$ and $\mathrm{MB}+\mathrm{TA}$ are predicted to provide effective serum concentrations when $\mathrm{MB}$ is administered i.m. once daily at a dose of $2 \mathrm{mg} / \mathrm{kg}$.

For fluoroquinolones as a group, the values of integrated PKPD surrogates, $C_{\max } / \mathrm{MIC}$ and $\mathrm{AUC}_{24 \mathrm{~h}} / \mathrm{MIC}$, for successful bacteriological outcome, of $10: 1$ and $125 \mathrm{~h}$ (or greater), respectively, have been generally accepted by the scientific community. However, they are based on both the results of experimental studies in laboratory animals (which in many studies were immunosuppressed) and human clinical trial data (predominantly patients with severe lung infections). Moreover, the outcome of antimicrobial therapy, including the emergence of resistance, depends on a wide range of factors, including disease severity, causative microbial species and strain, pathogen load and immunocompetence (Lees et al., 2006). Ferran et al. (2007) demonstrated in an in vitro pharmacodynamic model that the likelihood of selection of $E$. coli mutants resistant to $\mathrm{MB}$ was increased when the initial inoculum size was high. The same group reached a similar conclusion when $\mathrm{MB}$ was investigated in a rat lung infection model based on Klebsiella 
pneumoniae and a mouse thigh infection model based on E. coli (Ferran et al., 2009; Kesteman et al., 2009). Indeed, the murine model indicated that only the time within the mutant selection window (and not AUC/MIC or $C_{\max } / \mathrm{MIC}$ ) was a good predictor for prevention of emergence of resistance (Ferran et al., 2009). Mutant selection window is that period for which plasma concentrations are greater than MIC but less than mutant prevention concentration (MPC). The MPC is the lowest drug concentration that prevents the growth of the least susceptible first-step resistant mutants. In the rat lung infection model, prevention of resistance required an AUC/MIC ratio of $189 \mathrm{~h}$ for a low $\left(10^{5} \mathrm{cfu}\right)$ inoculum, while for a high $\left(10^{9} \mathrm{cfu}\right)$ inoculum, resistant subpopulation enrichment occurred for AUC/MIC ratios up to $756 \mathrm{~h}$ (Kesteman et al., 2009).

In summary, success in killing bacteria can be correlated with one or more of the indices, $\mathrm{AUC}_{24 \mathrm{~h}} / \mathrm{MIC}, C_{\max } / \mathrm{MIC}$ and $T>$ MIC. However, they may be less appropriate to ensure that resistance does not emerge. This is because MIC defines efficacy and potency for the whole population and not for subpopulations, with varying susceptibilities. Olofsson et al. (2007) suggested that $\mathrm{AUC}_{24 \mathrm{~h}} / \mathrm{MPC}$ could be used as an indicator of the exposure required to prevent the selection of resistant mutants. They reported that an $\mathrm{AUC}_{24 \mathrm{~h}} / \mathrm{MPC}$ ratio $\geq 22 \mathrm{~h}$ prevented the resistance development in E. coli. The MPC of strains of $M$. haemolytica isolated from calves with BRD is not known but will be the focus of future studies.

\section{PK-PD modelling of $M B$}

As an alternative to using the widely quoted ratios of 10:1 for $C_{\text {max }} / \mathrm{MIC}$ and $125 \mathrm{~h}$ for $\mathrm{AUC}_{24 \mathrm{~h}} / \mathrm{MIC}$ for fluoroquinolones, it is desirable to determine for individual drugs acting against specific pathogens, the actual ratios required to provide differing levels of growth inhibition. In this study, the PK-PD modelling approach was applied to MB against a pathogenic strain of M. haemolytica. Based on exposure over a $24 \mathrm{~h}$ period, the data indicated that numerically lower values of $\mathrm{AUC}_{24 \mathrm{~h}} / \mathrm{MIC}$ were required to achieve both 3 and 4-log reductions in bacterial count with $\mathrm{MB}+\mathrm{TA}$ compared with MB alone for all three matrices (serum, exudate and transudate) investigated. However, the differences were not statistically significant, so that greater bacterial kill of $\mathrm{MB}$ in the presence of TA cannot be claimed.

For $\mathrm{MB}$, the modelled $\mathrm{AUC}_{24 \mathrm{~h}} / \mathrm{MIC}$ ratios providing a 3-log reduction in bacterial count were $92 \mathrm{~h}$ (serum), $77 \mathrm{~h}$ (exudate) and $77 \mathrm{~h}$ (transudate), giving a mean of $82 \mathrm{~h}$ for the three fluids. Corresponding modelled values for $\mathrm{MB}+\mathrm{TA}$ were $69 \mathrm{~h}$ (serum), $69 \mathrm{~h}$ (exudate) and $66 \mathrm{~h}$ (transudate), giving a mean of $68 \mathrm{~h}$. Based on the relationship Dose $=\mathrm{Cl} / \mathrm{F} \times \mathrm{AUC}_{24} \mathrm{~h} / \mathrm{MIC} \times \mathrm{MIC}_{90}$, these data indicate a MB once daily dosage of $0.44 \mathrm{mg} / \mathrm{kg}$ for the strain of organism used in this study (serum MIC = $0.040 \mu \mathrm{g} / \mathrm{mL}$ ). The corresponding estimated dose for $\mathrm{MB}+\mathrm{TA}=0.36 \mathrm{mg} / \mathrm{kg}$. However, Meunier et al. (2004) reported $\mathrm{MIC}_{90}$ values for bovine $M$. haemolytica isolates which varied considerable from year to year (between 1994/1995 and 2001) from $0.108 \mu \mathrm{g} / \mathrm{mL}(1998)$ to $0.420 \mu \mathrm{g} / \mathrm{mL}$ (2001). The mean value over 8 years was $0.240 \mu \mathrm{g} / \mathrm{mL}$, whereas previously
Drugeon et al. (1997) reported an $\mathrm{MIC}_{90}$ of $0.17 \mu \mathrm{g} / \mathrm{mL}$. Based on the $0.24 \mu \mathrm{g} / \mathrm{mL}$ value, the calculated dose for bactericidal activity is $2.65 \mathrm{mg} / \mathrm{kg}$ for $\mathrm{MB}$ and $2.19 \mathrm{mg} / \mathrm{kg}$ for $\mathrm{MB}+\mathrm{TA}$. Overall, therefore, the present findings support the currently recommended daily dose of $\mathrm{MB}$ of $2 \mathrm{mg} / \mathrm{kg}$.

\section{CONCLUSIONS}

This study established no difference in the PK profile of MB when administered in combination with TA. Ex vivo findings demonstrated the ability of MB to eradicate a pathogenic strain of M. haemolytica in serum, exudate and transudate samples. The latter fluids are in the extracellular compartment, and most bacteria in most infections are present in these spaces (Kissane, 1997). The data suggest that MB, either alone or in combination with TA, should be therapeutically successful in infectious diseases of calves caused by M. haemolytica at the dosage of $2 \mathrm{mg} / \mathrm{kg}$ administered every $24 \mathrm{~h}$ based on a $\mathrm{MIC}_{90}$ value of $0.240 \mu \mathrm{g} / \mathrm{mL}$.

\section{ACKNOWLEDGMENTS}

P. K. Sidhu was supported by a scholarship from the British Council. This study was supported by Vetoquinol Animal Health. Mike Andrews and Patricia Marks provided skilled technical assistance.

\section{REFERENCES}

Aliabadi, F.S. \& Lees, P. (2001) Pharmacokinetics and pharmacodynamics of danofloxacin in serum and tissue fluids of goats following intravenous and intramuscular administration. American Journal of Veterinary Research, 62, 1979-1989.

Aliabadi, F.S. \& Lees, P. (2002) Pharmacokinetics and pharmacokinetic/pharmacodynamic integration of marbofloxacin in calf serum, exudate and transudate. Journal of Veterinary Pharmacology and Therapeutics, 25, 161-174.

Aliabadi, F.S., Landoni, M.F. \& Lees, P. (2003) Pharmacokinetics (PK), pharmacodynamics (PD), and PK-PD integration of danofloxacin in sheep biological fluids. Antimicrobial Agents and Chemotherapy, 47, 626-635.

Brown, S.A. (1996) Fluoroquinolones in animal health. Journal of Veterinary Pharmacology and Therapeutics, 19, 1-14.

Clarke, C.R. (1989) Tissuee-chamber modeling systems - applications in veterinary medicine. Journal of Veterinary Pharmacology and Therapeutics, 12, 349-368.

Deleforge, J., Thomas, E., Davot, J.L. \& Boisrame, B. (1994) A field evaluation of the efficacy of tolfenamic acid and oxytetracycline in the treatment of bovine respiratory disease. Journal of Veterinary Pharmacology and Therapeutics, 17, 43-47.

Dova, S.W., San Andres, M.D., Gonzalez, F., San Andres, M.I., De Lucas, J.J. \& Rodriguez, C. (2006) Pharmacokinetic behaviour and pharmacokinetic/pharmacodynamic integration of marbofloxacin after subcutaneous administration in goats. Veterinary Journal, 174, 425-427.

Drugeon, H., Thomas, V., Guillardean, L. \& Thomas, E. (1997) Antibacterial activity of marbofloxacin against bovine respiratory isolates. 
Journal of Veterinary Pharmacology and Therapeutics, 20 (Suppl. 1), 138139.

Drusano, G.L. (2003) Prevention of resistance: a goal for dose selection for antimicrobial agents. Clinical Infectious Diseases, 36 (Suppl.), S42-S50.

Dutta, N.K., Mazumdar, K., Dastidar, S.G. \& Park, J.H. (2007) Activity of diclofenac used alone and in combination with streptomycin against Mycobacterium tuberculosis in mice. International Journal of Antimicrobial Agents, 30, 336-340.

Fabrega, A., Sanches-Cespedes, J., Soto, S. \& Vila, J. (2008) Quinolone resistance in the food chain. International Journal of Antimicrobial Agents, 31, 307-315.

Ferran, A.A., Dupouy, V., Toutain, P.L. \& Bousquet-Melou, A. (2007) Influence of inoculum size on the selection of resistant mutants of Escherichia coli in relation to mutant prevention concentrations of marbofloxacin. Antimicrobial Agents and Chemotherapy, 51, 4163-4166.

Ferran, A.A., Kesteman, A.S., Toutain, P.L. \& Bousquet-Melou, A. (2009) Pharmacokinetic/pharmacodynamic analysis of the influence of inoculum size on the selection of resistance in Escherichia coli by a quinolone in a mouse thigh bacterial infection model. Antimicrobial Agents and Chemotherapy, 53, 3384-3390.

Forrest, A., Nix, D.E. \& Ballow, C.H. (1993) Pharmacodynamics of intravenous ciprofloxacin in seriously ill patients. Antimicrobial Agents and Chemotherapy, 37, 1073-1081.

Haritova, A.M., Rusenova, N.V., Parvanov, P.R., Lashev, L.D. \& FinkGremmels, J. (2006) Integration of pharmacokinetic and pharmacodynamic indices of marbofloxacin in turkeys. Antimicrobial Agents and Chemotherapy, 50, 3779-3785.

Higgins, A.J., Lees, P. \& Wright, J.A. (1984) Tissue-cage model for the collection of inflammatory exudate in ponies. Research in Veterinary Science, 36, 284-289.

Ismail, M. \& El-Kattan, Y.A. (2007) Comparative pharmacokinetics of marbofloxacin in healthy and Mannheimia haemolytica infected calves. Research in Veterinary Science, 82, 398-404.

Kesteman, A.S., Ferran, A.A., Perrin-Guyomard, A., Laurentie, M., Sanders, P., Toutain, P.L. \& Bousquet-Melou, A. (2009) Influence of inoculum size and marbofloxacin plasma exposure on the amplification of resistant subpopulations of Klebsiella pneumoniae in a rat lung infection model. Antimicrobial Agents and Chemotherapy, 53, 47404748 .

Kissane, J.M. (1997) Bacterial Diseases. In Pathology. Eds Anderson, W.A.D. \& Kissane, J.M., pp. 369-414. Mosby, St. Louis, MO.

Kruszewska, H., Zareba, T. \& Tyski, S. (2002) Search of antimicrobial activity of selected non-antibiotic drugs. Acta Poloniae Pharmaceutica, $59,436-439$.

Lees, P., Concordet, D., Aliabadi, F.S. \& Toutain, P.L. (2006) Drug selection and optimization of dosage schedules to minimize antimicrobial resistance. In Antimicrobial Resistance in Bacteria of Animal Origin. Eds Aarestrup, F.M., pp. 49-71. ASM Press, Washington, D.C.

Meunier, D., Acar, J.F., Martel, J.L., Kroemer, S. \& Valle, M. (2004) Seven years survey of susceptibility to marbofloxacin of bovine pathogenic strains from eight European countries. International Journal of Antimicrobial Agents, 24, 70-80.

Olofsson, S.K., Marcusson, L.L., Stromback, A., Hughes, D. \& Cars, O. (2007) Dose-related selection of fluoroquinolone-resistant Escherichia coli. Journal of Antimicrobial Chemotherapy, 60, 795-801.

Petracca, K., Riond, J.L., Graser, T. \& Wanner, M. (1993) Pharmacokinetics of the gyrase inhibitor marbofloxacin: influence of pregnancy and lactation in sows. Journal of Veterinary Medicine A., 40, 73-79.

Robertson, S.A. \& Taylor, P.M. (2004) Pain management in cats - past, present and future. Part-2. Treatment of pain-clinical pharmacology. Journal of Feline Medicine and Surgery, 6, 321-333.

Sarasola, P., Lees, P., Aliabadi, F.S., McKellar, Q.A., Donachie, W., Marr, K.A., Sunderland, S.J. \& Rowan, T.G. (2002) Pharmacokinetic and pharmacodynamic profiles of danofloxacin administered by two dosing regimens in calves infected with Mannheimia (Pasteurella) haemolytica. Antimicrobial Agents and Chemotherapy, 46, 3013-3019.

Schneider, M., Thomas, V., Boisrame, B. \& Deleforge, J. (1996) Pharmacokinetics of marbofloxacin in dogs after oral and parenteral administration. Journal of Veterinary Pharmacology and Therapeutics, 19, 56-61.

Shem-Tov, M., Ziv, G., Glickman, A. \& Saran, A. (1997) Pharmacokinetics and penetration of marbofloxacin from blood into the milk of cows and ewes. Journal of the American Veterinary Medical Association, 44, 511-519.

Sidhu, P.K., Aliabadi, F.S., Andrews, M. \& Lees, P. (2003) Tissue chamber model of acute inflammation in farm animal species. Research in Veterinary Science, 74, 67-77.

Sidhu, P.K., Landoni, M.F. \& Lees, P. (2005) Influence of marbofloxacin on the pharmacokinetics and pharmacodynamics of tolfenamic acid in calves. Journal of Veterinary Pharmacology and Therapeutics, 28, 109119.

Sidhu, P.K., Alibadi, F.S., Landoni, M.F. \& Lees, P. (2006a) Pharmacokinetic and pharmacodynamic interactions of marbofloxacin with tolfenamic acid in calves. Journal of Veterinary Pharmacology and Therapeutics, 29 (Suppl. 1), 253-254.

Sidhu, P.K., Landoni, M.F. \& Lees, P. (2006b) Pharmacokinetic and pharmacodynamic interactions of tolfenamic acid and marbofloxacin in goats. Research in Veterinary Science, 80, 79-90.

Sidhu, P.K., Landoni, M.F., Aliabadi, F.S. \& Lees, P. (2010a) PK-PD integration and modeling of marbofloxacin in sheep. Research in Veterinary Science, 88, 134-141.

Sidhu, P.K., Landoni, M.F., Aliabadi, F.S. \& Lees, P. (2010b) Pharmacokinetic and pharmacodynamic modelling of marbofloxacin administered alone and in combination with tolfenamic acid in goats. The Veterinary Journal, 184, 219-229.

Spreng, M., Deleforge, J., Thomas, V., Boisrame, B. \& Drugeon, H. (1995) Antibacterial activity of marbofloxacin: a new fluoroquinolone for veterinary use against canine and feline isolates. Journal of Veterinary Pharmacology and Therapeutics, 18, 284-289.

Sullivan, M., Cooper, B.W., Nightingale, C.H., Quintiliani, R. \& Lawlor, M.T. (1993) Evaluation of the efficacy of the ciprofloxacin against streptococcus pneumoniae by using a mouse protection model. Antimicrobial Agents and Chemotherapy, 37, 234239.

Thomas, V., Deleforge, J. \& Boisrame, B. (1994a). Pharmacokinectics of marbofloxacin in pre-ruminant and ruminant cattle. In 6th EAVPT Congress Proceedings, pp. 60-61, Blackwell Scientific Publications, Edinburgh, Scotland.

Thomas, V., Deleforge, J., Boisrame, B. \& Espinasse, J. (1994b). Pharmacokinetics of marbofloxacin in healthy and sick pre-ruminant calves. In 6th EAVPT Congress Proceedings, p. 61, Blackwell Scientific Publications, Edinburgh, Scotland.

Thomas, V., Gruet, P., Pommier, P. \& Wessel-Robert, S. (1998a) Maladies respiratoives des porcs charcutiers: marbocyl $2 \%$ versus amoxycilline. Action Veterinaire, 1462, 14-15.

Thomas, E., Madelenat, A., Davot, J.L. \& Boisrame, B. (1998b) Clinical efficacy and tolerance of marbofloxacin and tetracycline in the treatment of bovine respiratory disease. Revue Medecine Veterinaire, 174, 21-27.

Thomas, E., Caldow, G.L., Borell, D. \& Davot, J.L. (2001) A field comparison of the efficacy and tolerance of marbofloxacin in the treatment of bovine respiratory disease. Journal of Veterinary Pharmacology and Therapeutics, 24, 353-358.

Thomas, A., Nicolas, C., Dizier, I., Mainil, J. \& Linden, A. (2003) Antibiotic susceptibilities of recent isolates of Mycoplasma bovis in Belgium. Veterinary Record, 153, 428-431. 
Toutain, P.L. (2002) The pharmacokinetic-pharmacodynamic approach to a rational dosage regimen for antibiotics. Research in Veterinary Science, 73, 105-114.

Toutain, P.L. (2003a) Pharmacokinetics/pharmacodynamics integration in dosage regimen optimization for veterinary medicine. Journal of Veterinary Pharmacology and Therapeutics, 26 (Suppl. 1), 1-8.

Toutain, P.L. (2003b) Antibiotic treatment of animals - a different approach to rational dosing. The Veterinary Journal, 165, 98-100.
Toutain, P.L. \& Lees, P. (2004) Integration and modeling of pharmacokinetic and pharmacodynamic data to optimize dosage regimens in veterinary medicine. Journal of Veterinary Pharmacology and Therapeutics, 27, 467-477.

Zeitlinger, M., Sauermann, R., Fille, M., Hausdorfer, J., Leitner, I. \& Muller, M. (2008) Plasma protein binding of fluoroquinolones affects antimicrobial activity. Journal of Antimicrobial Chemotherapy, 61, 561567. 